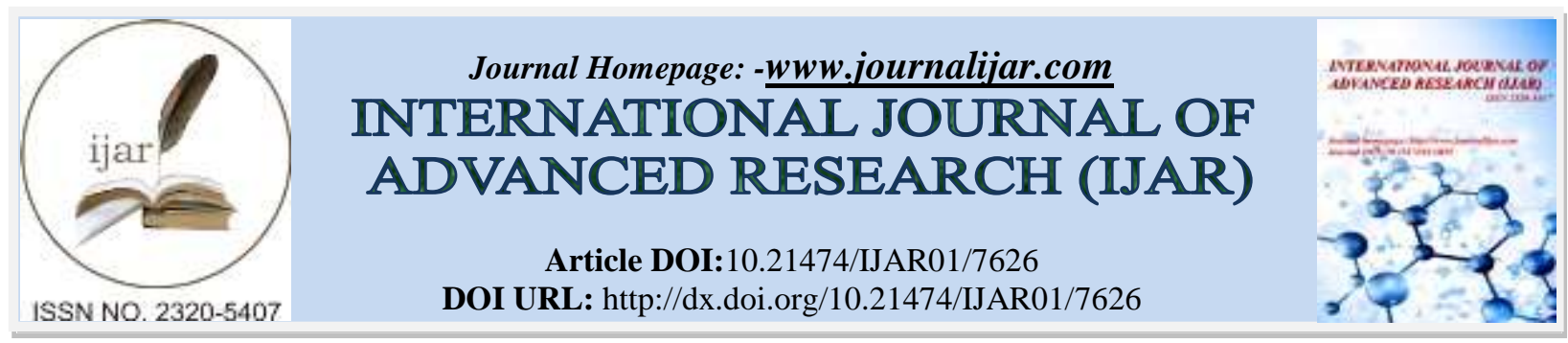

RESEARCH ARTICLE

\title{
COLOUR OF CORRIEDALE WOOL AND ITS EFFECT ON DYEING.
}

Neimaur $\mathrm{K}^{\mathbf{1}}$, Fernández $\mathrm{A}^{\mathbf{2}}$, Pérez $\mathrm{V}^{\mathbf{2}}$, Sienra $\mathrm{I}^{\mathbf{1}}$, Urioste $\mathrm{JI}^{\mathbf{3}}$ and Kremer $\mathrm{R}^{\mathbf{1}}$.

1. Sheep and Wool Department, Veterinary Faculty, UDELAR, Lasplaces 1550, Montevideo, Uruguay.

2. Depto. Textiles, Lana Bruta, Tops y Cueros. Laboratorio Tecnológico del Uruguay. Av. Italia 6201, Montevideo, Uruguay.

3. Animal Production and Pastures Department, College of Agriculture, UDELAR, Garzón 780, Montevideo, Uruguay.

\section{Manuscript Info}

Manuscript History

Received: 23 June 2018

Final Accepted: 25 July 2018

Published: August 2018

\begin{abstract}
The objective of the essay was to study the effect of wool scoured color on the color acquired after dyeing and the interaction between wool yellowness with different light stains in Corriedale wool. According to the value of yellowness index (Y-Z) measured using a Hunterlab spectrophotometer, 5 homogeneous carding webs were prepared (mean Y-Z values of $-0.84,0.74,2.50,4.77$ and 7.79 , respectively). A dyeing procedure was performed

using three acid colorant: Blue Erionyl AR, Yellow Erionyl A-3G and Red Erionyl A-3G. Color measurements of dyeing samples using the CIELAB L* $a^{*} b^{*}$ system were carried out. The total color difference $(\Delta E)$ of the dyed samples was calculated from $L^{*}, a^{*}, b^{*}$ coordinates. Significant effects $(\mathrm{P}<0.001)$ of dye and carding web initial color were found on all color parameters. $\Delta \mathrm{E}$ values increased with increasing values of initial $\mathrm{Y}-\mathrm{Z}$, the yellower the sample was, the higher the $\Delta \mathrm{E}$ that presented. The position of cut off point in the $\mathrm{Y}-\mathrm{Z}$ scale from which difficulties in staining were evident, was under 0.74. In conclusion, a difference in color in dyed wool with pastel shades can be visually detected even starting from low values of scoured color, and these differences vary with dyes used.
\end{abstract}

Copy Right, IJAR, 2018,. All rights reserved.

\section{Introduction:-}

Many parameters determine the quality of wool: fibre diameter, staple length, wool color and yield. Wool scoured color can vary from white, through creamy to yellow colorations and it is important as it indicates the color palette that can be used for dyeing. The presence of yellow colorations in wool is the result of a complex interaction between fleece structure, non-fibre components, bacteria (Cottle et al., 1992) and environmental factors such as warm temperatures, high rainfall and moist conditions (Aitken et al., 1994; Reid, 1994). The incidence of these colorations varies with locations and breeds.

Clean wool color can be measured using a Colorimeter that brings information of yellowness index (Y-Z) and luminosity or brightness (Y) (Wood, 2002). The values of Y-Z (CIE D65/10) may vary approximately from -2.0 (extremely white) to 12.0 (bright yellow) (IWTO 56). A higher Y value indicates a better color due to higher brightness. 
Corriedale breed represents the $45 \%$ of the Uruguayan flock (MGAP, 2017). Its wool is characterized by fibre diameter between 25 and $30 \mu \mathrm{m}$, high yield (78\%), good staple strength (33.1N/ktex), low vegetable matter content, but with an average scoured color of 4.2 Y-Z units, which is a cream color (Capurro, 1996). For this breed, it is considered that Y-Z values below 2.0 are very good, 2.0 to 4.0 acceptable and higher than 4.0, insufficient color (Peinado et al., 1999). Corriedale wool presents a creamier coloration than Australian Merino wool (Abella, 2011).

The goal of wool dyeing is to obtain a colored product in the desired shade, uniform in intensity and tone of color, produced by an economic process and exhibiting satisfactory fastness properties in the finished product (Peter and Rouette, 1989). The presence of yellow colorations in wool has been associated with poor performance of dyeing (Rottenbury, 1984; Marler and Samuelsdorff, 1987; Whiteley, 1987; Reid, 1993), limiting the range of colors that it can be dyed. In the majority of end-uses, the natural color of wool is adequately covered by most dyeing, but if fashion dictates a very white or a bright pastel colored article then it is necessary that the fibre should be given some sort of bleaching procedure (Duffield and Lewis, 1985). However, this practice may lead to unnecessary fibre damage or to color instability (Lewis, 2009).

While there are several studies about dyeing Merino wool (Milligan, 1966; Brady, 2005), there is no available information about dyeing Corriedale wool. Moreover, there is no information about where in the $\mathrm{Y}-\mathrm{Z}$ scale is the cutoff point from which difficulties in staining with pastel colors are notorious and if the performance of this wool against dyeing process varies with different pastel shades.

The knowledge of Corriedale wool performance when dyeing with pastel colors would be of interest to validate or quantify the suggestions from the industry on the importance of producing whiter wool. Thus, the objective of the essay was to study the effects of wool scoured color on the color acquired after dyeing and the interaction between wool yellowness with the different light stains in Corriedale wool.

\section{Material and Methods:-}

Preparation of wool samples

Wool samples from 200 Corriedale sheep of the Migues Experimental Station of Veterinary Faculty (Uruguay) were extracted from midside during shearing. They were scoured in a 4 pools-carwash, using hot water and a nonionic detergent diluted to $25 \%$ in the first three pools. They were centrifuged, dried at a temperature of $60^{\circ} \mathrm{C}$ and conditioned in the laboratory at $20^{\circ} \mathrm{C} \pm 2$ and $65 \% \pm 3$ of relative humidity. After that, they were carded in order to remove vegetable matter. Clean wool colour was measured using a Hunterlab Miniscan XE spectrophotometer (IWTO 56), obtaining data of yellowness index and luminosity or brightness. According to the value of Y-Z obtained and considering the average scoured colour of 4.2 Y-Z units, recorded by Capurro 1996) in the characterization of Corriedale Uruguayan wool, 5 groups of samples were prepared (Table 1).

Table 1:-Y-Z value of the different groups of samples prepared

\begin{tabular}{|l|l|}
\hline Group & Y-Z \\
\hline 1 & $0.5-1.0$ \\
\hline 2 & $2.0-2.5$ \\
\hline 3 & $4.0-4.5$ \\
\hline 4 & $>7.0$ \\
\hline 5 (Control) & $<0.0$ \\
\hline
\end{tabular}

Samples in each group were blended and carded in a carding machine, obtaining 5 homogeneous carding webs.

\section{Measurements and analisis}

Clean wool color of the 5 carding webs was measured in order to check color homogenity while mean fibre diameter (MFD) and coefficient variation of fibre diameter (CV) were determined using a Sirolan Laserscan (IWTO 12, 2009).

The carding process, fibre diameter and wool color measurements and the dyeing procedure were carried out in Laboratorio Tecnológico del Uruguay (LATU). 


\section{Dyeing Procedure}

Three acid colorants were used: Blue Erionyl AR, Yellow Erionyl A-3G and Red Erionyl A-3G. The dyeing procedure was performed in a Roaches Dyeing equipment. Each wool carding web was dyed with the 3 colorants, so 12 dyeing procedures were done. The equipment had 10 metal containers, thus for each dyeing process, 10 samples of $4 \mathrm{~g}$ of wool were used, 9 of the corresponding carding web and 1 control sample (Y-Z lower than zero).

A general dyeing bath was prepared with $2000 \mathrm{~mL}$ of water, acetic acid (drops) and the selected dye. The quantity of dye used for each color and card web was $0.0008 \mathrm{~g}$ for Yellow Erionyl A-3G and Blue Erionyl AR and 0.0003g for Red Erionyl A-3G. The bath ratio was $1 / 50$ (wool gram $/ 50 \mathrm{~mL}$ of water). Wool samples were previously dipped in water in order to be wetted. The dyeing bath $(200 \mathrm{~mL})$ was placed in each metal container and wet wool was added. The dyeing equipment had to be at a temperature of $40^{\circ} \mathrm{C}$ until the placement of the metal containers inside. The elevation of the bath temperature was $1{ }^{\circ} \mathrm{C}$ per minute, up to $98^{\circ} \mathrm{C}$, temperature at which the samples were for 40-60 minutes; next, the bath temperature was lowered to $80^{\circ} \mathrm{C}$ (Huntsman International LLC, 2007). Finally, wool samples were air dried and manually carded.

\section{Color measurements}

Color measurement of the dyed samples was carried out using a Hunterlab Miniscan XE spectrophotometer with illuminant D65 and $10^{\circ}$ observer (geometry $45^{\circ} / 0^{\circ}$ ). Data obtained were $\mathrm{L}^{*}, \mathrm{a}^{*}, \mathrm{~b}^{*}$ coordinates.

\section{Statistical analysis}

Means and standard deviation of $\mathrm{L}^{*}, \mathrm{a}^{*}, \mathrm{~b}^{*}$ in the 4 carding webs and the control one stained by the 3 dyes were determined. An analisis of variance (ANOVA) was carried out to analyse the effect of carding web initial color (Group 1: Y-Z 0.5-1, Group 2: Y-Z 2-2.5, Group 3: Y-Z 4-5, Group 4: Y-Z>7) and the effect of dye used (Blue Erionyl AR, Yellow Erionyl A-3G and Red Erionyl A-3G) on the colorimetric characteristics. The interactions between these effects were also determined. The total color difference of the dyed samples was calculated from the $\mathrm{L}^{*}, \mathrm{a}^{*}, \mathrm{~b}^{*}$ coordinates by applying the following equation:

Total color difference $(\Delta \mathrm{E})=\sqrt{(\Delta \mathrm{L} *)^{2}+(\Delta \mathrm{a} *)^{2}+(\Delta \mathrm{b} *)^{2}}$

Where $\Delta \mathrm{L}=\mathrm{L}^{*}$ sample $-\mathrm{L}^{*}$ standard; $\Delta \mathrm{a}^{*}=\mathrm{a}^{*}$ sample $-\mathrm{a}^{*}$ standard; $\Delta \mathrm{b}^{*}=\mathrm{b}^{*}$ sample $-\mathrm{b}^{*}$ standard (ASTM Standards, D2244-11, 2011).

A multiple linear regression was fitted to obtain prediction equations of $\Delta \mathrm{E}$ from $\Delta \mathrm{L}, \Delta \mathrm{a}$ and $\Delta \mathrm{b}$ variables. All the statistical evaluations were performed with STATA statistical package program (Stata Statistical Software, 2011).

\section{Results and discussion:-}

\section{Physical measurement of samples before dyeing}

The 5 carding webs defined by their Y-Z value showed similar values of mean fibre diameter (between 25.8 and $27.2 \mu \mathrm{m})$, comparable with those reported for this wool breed in Uruguay (Abella et al., 2010) $(25-32 \mu \mathrm{m})$ and considering that hogget's wool is finer. Table 2 shows clean wool color and fibre diameter characteristics of the card webs.

Table 2:-Means and standard deviation of clean wool colour, mean fibre diameter and coefficient of variation of fibre diameter of the carding webs.

\begin{tabular}{|l|l|l|l|}
\hline Carding web & Color $(\mathrm{Y}-\mathrm{Z})$ & MFD $(\mu \mathrm{m})$ & CV $(\%)$ \\
\hline C1 & $0.74 \pm 0.09$ & $25.81 \pm 0.11$ & $22.4 \pm 0.17$ \\
\hline C2 & $2.50 \pm 0.09$ & $26.72 \pm 0.06$ & $23.5 \pm 0.19$ \\
\hline C3 & $4.77 \pm 0.08$ & $26.25 \pm 0.12$ & $24.9 \pm 0.22$ \\
\hline C4 & $7.79 \pm 0.10$ & $27.21 \pm 0.07$ & $24.9 \pm 0.25$ \\
\hline Co & $-0.84 \pm 0.06$ & $26.63 \pm 0.05$ & $23.8 \pm 0.13$ \\
\hline
\end{tabular}

$\mathrm{C} 1=$ Carding web $1 ; \mathrm{C} 2=$ Carding web 2; C3= Carding web 3; C4= Carding web 4; $\mathrm{Co}=$ Control carding web.

\section{Colorimetric measurement}

The CIELAB L* a* b* system is derived from the X, Y, Z system, and is preferred by dyers because it facilitates color difference measurements, important for the matching of dyes (Wood, 2002). The value of lightness (L*) refers to level of lightness or darkness of the produced shade, and ranges from O (black) to 100 (white). The $\mathrm{a}^{*}$ parameter 
represents the red/green value (positive sign=red, negative sign=green) and $b^{*}$ parameter, the yellow/blue value (positive sign=yellow, negative sign=blue).

The samples dyed with Yellow Erionyl A-3G showed increasing values of $b^{*}$ coordinate. This fact should be expected as we are adding a yellow dye to a cream-yellow base, intensifying $\mathrm{b}^{*}$ values towards the yellow region. Moreover, these $b^{*}$ values were positive and the highest obtained from the three dyes used (16.94 to 22.92).

For the Blue Erionyl AR, negative values of a* coordinate were observed, indicating shifting of this color coordinate towards the green region of the color space diagram. Secondly, increasing positive values of the $b^{*}$ coordinate from $\mathrm{C} 1$ to $\mathrm{C} 4$ were obtained, instead of the negative values that would be expected for this blue staining, demonstrating an increasing change towards the yellow region, possibly due to the increasing wool color base. Lightness also showed a reduction from values of 74.58 to 72.61 .

In the carding webs dyed with Red Erionyl A-3G, a decrease of lightness from $\mathrm{C} 1$ to $\mathrm{C} 4$ was produced while an increase in $b^{*}$ coordinate was obtained.

In Table 3, means and standard deviations of color parameters of the carding webs dyed with the three colorants are showed.

Table 3:-Mean and standard deviation of Colorimetric data $\left(\mathrm{L}^{*}, \mathrm{a}^{*}, \mathrm{~b}^{*}\right)$ of the different carding webs dyed with three colorants.

\begin{tabular}{|c|c|c|c|c|}
\hline Dye & Carding web & $\mathbf{L}^{*}$ & $\mathbf{a}^{*}$ & $\mathbf{b}^{*}$ \\
\hline \multirow{5}{*}{$\begin{array}{l}\text { Yellow Erionyl } \\
\text { A-3G }\end{array}$} & Co & $80.12 \pm 0.26$ & $-1.32 \pm 0.36$ & $19.04 \pm 0.39$ \\
\hline & $\mathrm{C} 1$ & $81.25 \pm 0.25$ & $-1.27 \pm 0.24$ & $17.22 \pm 0.39$ \\
\hline & $\mathrm{C} 2$ & $79.34 \pm 0.25$ & $-0.32 \pm 0.10$ & $16.94 \pm 0.44$ \\
\hline & $\mathrm{C} 3$ & $79.37 \pm 0.13$ & $-0.44 \pm 0.28$ & $21.92 \pm 0.22$ \\
\hline & $\mathrm{C} 4$ & $79.30 \pm 0.43$ & $-0.53 \pm 0.21$ & $22.92 \pm 0.56$ \\
\hline \multirow{5}{*}{ Blue Erionyl AR } & $\mathrm{Co}$ & $74.50 \pm 0.23$ & $-5.19 \pm 0.66$ & $1.25 \pm 0.41$ \\
\hline & $\mathrm{C} 1$ & $74.58 \pm 0.39$ & $-6.03 \pm 0.55$ & $2.39 \pm 0.50$ \\
\hline & $\mathrm{C} 2$ & $73.72 \pm 0.13$ & $-4.54 \pm 0.31$ & $4.50 \pm 0.27$ \\
\hline & C3 & $73.56 \pm 0.35$ & $-5.53 \pm 0.25$ & $5.18 \pm 0.36$ \\
\hline & $\mathrm{C} 4$ & $72.61 \pm 0.39$ & $-6.61 \pm 0.22$ & $6.40 \pm 0.27$ \\
\hline \multirow{5}{*}{ Red Erionyl A-3G } & $\mathrm{Co}$ & $75.88 \pm 0.19$ & $11.14 \pm 0.34$ & $9.40 \pm 0.13$ \\
\hline & $\mathrm{C} 1$ & $77.47 \pm 0.12$ & $10.56 \pm 0.23$ & $9.08 \pm 0.10$ \\
\hline & $\mathrm{C} 2$ & $74.89 \pm 0.30$ & $8.80 \pm 0.13$ & $11.73 \pm 0.43$ \\
\hline & $\mathrm{C} 3$ & $74.37 \pm 0.48$ & $10.16 \pm 0.54$ & $12.58 \pm 0.21$ \\
\hline & $\mathrm{C} 4$ & $73.67 \pm 0.28$ & $12.52 \pm 0.28$ & $14.86 \pm 0.38$ \\
\hline
\end{tabular}

$\mathrm{C} 1=$ Carding web $1 ; \mathrm{C} 2=$ Carding web $2 ; \mathrm{C} 3=$ Carding web 3; $\mathrm{C} 4=$ Carding web $4 ; \mathrm{Co}=$ Control carding web

Effect of carding web initial color and dye used on the colorimetric characteristics

A significant dye effect $(\mathrm{P}<0.001)$ on all color parameters was found, as well as a card web initial color effect $(\mathrm{P}<0.001)$. As initial $\mathrm{Y}-\mathrm{Z}$ values increased from $\mathrm{C} 1$ to $\mathrm{C} 4, \mathrm{~L}^{*}$ declined, which was concordant with Andrews et al. (1988). On the contrary, b* coordinates increased, becoming more yellow, which it would be explained by wool base color, which also got higher from $\mathrm{C} 1$ to $\mathrm{C} 4$. The interaction between carding web yelllowness and dye effects was significant $(\mathrm{P}<0.001)$.

Effects of card web initial color (Y-Z) and dye used on the colorimetric characteristics are showed in Table 4.

Table 4. Effect of card web initial color (Y-Z) and effect of dye used on the colorimetric characteristics ( $\left.L^{*}, a^{*}, b^{*}\right)$.

\begin{tabular}{|l|l|l|l|}
\hline & L$^{*}$ & $\mathbf{a}^{*}$ & $\mathbf{b}^{*}$ \\
\hline Yellow Erionyl A-3G & $79.82 \pm 0.88$ & $-0.64 \pm 0.49$ & $19.75 \pm 2.76$ \\
\hline Blue Erionyl AR & $73.62 \pm 0.77$ & $-5.68 \pm 0.84$ & $4.62 \pm 1.51$ \\
\hline Red Erionyl A-3G & $75.10 \pm 1.48$ & $10.51 \pm 1.38$ & $12.06 \pm 2.11$ \\
\hline
\end{tabular}




\begin{tabular}{|l|l|l|l|}
\hline Effect & $* * *$ & $* * *$ & $* * *$ \\
\hline $\mathrm{C} 1$ & $77.77 \pm 2.79$ & $1.08 \pm 7.12$ & $9.56 \pm 6.19$ \\
\hline $\mathrm{C} 2$ & $75.98 \pm 2.47$ & $1.31 \pm 5.68$ & $11.06 \pm 5.21$ \\
\hline $\mathrm{C} 3$ & $75.77 \pm 2.63$ & $1.39 \pm 6.67$ & $13.23 \pm 6.98$ \\
\hline C4 & $75.19 \pm 3.01$ & $1.79 \pm 8.14$ & $14.73 \pm 6.88$ \\
\hline Effect & $* * *$ & $* * *$ & $* * *$ \\
\hline C\#C & $* * *$ & $* * *$ & $* * *$ \\
\hline
\end{tabular}

$\mathrm{C} 1=$ Carding web 1; $\mathrm{C} 2=$ Carding web 2; C3= Carding web 3; $\mathrm{C} 4=$ Carding web 4; $\mathrm{Co}=\mathrm{Control}$ carding web; $* * *=$ significant $\mathrm{P}<0.001$

\section{Total color difference $(\Delta E)$}

It has been found that the summation of three, vector color-difference components $\left(L^{*}, a^{*}, b^{*}\right)$ into a single scalar value is very useful for determining whether a specimen color is within a specified tolerance from a standard (ASTM Standards, D2244-11, 2011). Moreover, it is interesting to find out if the human eye can also detect these significant differences. The parameter that provides this information is total color difference, calculated using a control-carding web. According to Bechtold (2007), a color difference of 1.0 is accepted as tolerable between two dyes when using synthetic dyes. Willis (1997) coincided with this value for commercial purposes.

In the current essay, the $\Delta \mathrm{E}$ values obtained for the three dyes were higher than 1.0 for all carding webs. It can be clearly seen that $\Delta \mathrm{E}$ values of the samples increased with increasing values of initial $\mathrm{Y}-\mathrm{Z}$ of the different carding webs (from $\mathrm{C} 1$ to $\mathrm{C} 4$ ), the yellower the sample was, the higher the $\Delta \mathrm{E}$ that presented. The highest $\Delta \mathrm{E}$ value (6.06) was obtained for the Red Erionyl A-3G colorant, while the lowest one (1.62) with Blue Erionyl AR. Considering carding webs, in $\mathrm{C} 1$, the highest $\Delta \mathrm{E}$ was recorded with Yellow Erionyl A-3G dye, while in $\mathrm{C} 4$ (the yellowest carding web), with Red Erionyl A-3G. Significant dye and carding web effects on $\Delta \mathrm{E}$ and a significant interaction between dye and carding web were obtained $(\mathrm{P}<0.001)$. In Fig. 1 , total color difference of each carding web dyed with the different colorants is presented.

Figure 1:-Total color difference $(\Delta \mathrm{E})$ of the carding webs dyed with the different colorants.

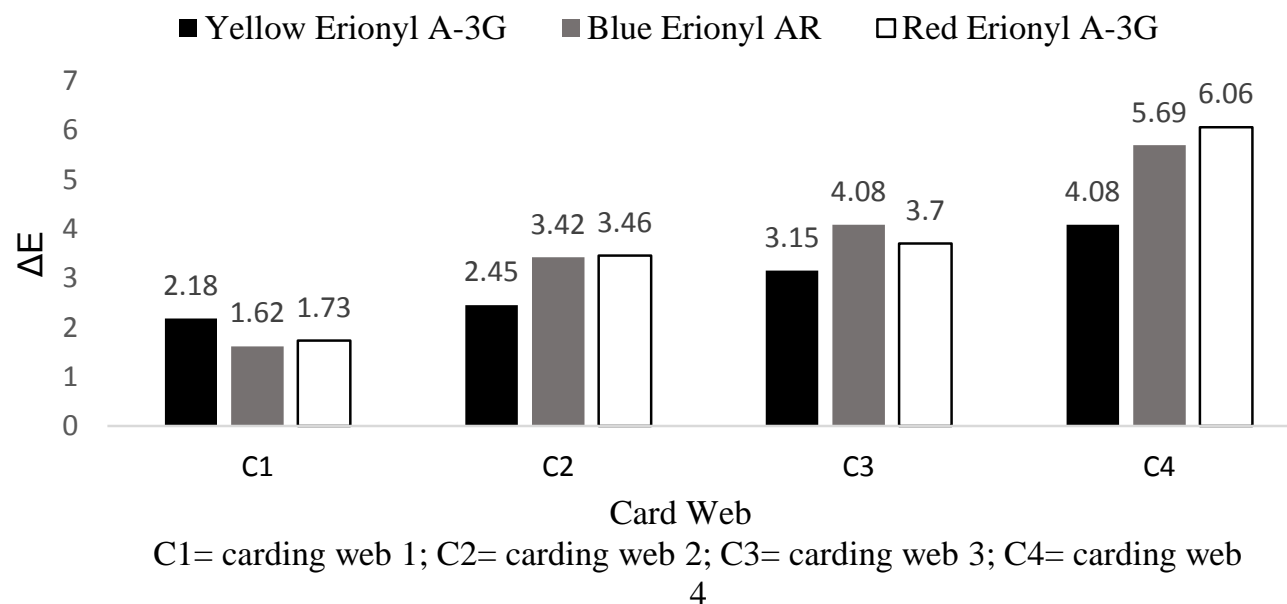

Multiple linear regression analysis was used to develop a model for predicting total color change from $\Delta \mathrm{L}^{*}, \Delta \mathrm{a}^{*}$ and $\Delta \mathrm{b}$. The results showed that the model, being significant at $\mathrm{P} \leq 0.05$, explained $74.6 \%$ of $\Delta \mathrm{E} . \Delta \mathrm{L}^{*}$ and $\Delta \mathrm{b}^{*}$ had both significant regression weights, indicating that for each unit increase in the $\Delta \mathrm{L}^{*}$ score, $\Delta \mathrm{E}$ decreased at 0.52 and that for each unit increase in the $\Delta \mathrm{b}^{*}$ score, $\Delta \mathrm{E}$ increased by 0.28 . Otherwise, $\Delta \mathrm{a}^{*}$ had no significant regression weight. The results indicated that the total color difference was mainly based on the differences in $b^{*}$ and $L^{*}$. This gave a pattern of movement of the axis $b^{*}$ toward the yellow region, possibly due to wool base color, and strengthened the suggestion that brightness decreases with wool yellowing.

According to Skinner (1958), wool-dyer requires wool slivers and tops with a perfect white color. It had been described that poor color limits the range of shades to which a wool can be dyed, often precluding its use in products 
requiring light pastel shades (Teasdale, 1995). Moreover, Wood (2003) suggested that a yellow wool cannot be dyed to a light pastel shade and hence it has a lower dyeing potential. The color difference found in wool with $\mathrm{Y}-\mathrm{Z}$ values lower than 1.0, demonstrated that for this kind of shade, color requirements might be higher. The position of cut off point in the Y-Z scale from which difficulties in staining with pastel colors were perceived was under 0.74 in this Corriedale wool. From this value on, subjective visually evaluation could detect differences in color and these differences varied with the pastel dye used. However, the human eye is the final arbiter in deciding not only at what point matches become unacceptable (Jaeckel and Ward, 1964), but also at what degrees of color change cause complaints.

\section{Conclusions:-}

This essay quantifies the significant effects of wool scoured color (yellowness) and pastel dyes on the acquired color of wool after dyeing. As Y-Z values of carding webs increased, total color difference determined after dyeing was greater. This difference was detected even in wool with Y-Z values lower than 1.0 and was mainly based on variations in $b^{*}$ and $\mathrm{L}^{*}$ parameters. From this value on, dyeing performance would be affecting the colour adquire after dyeing, with variation according to the pastel dye used.

\section{Acknowledgments:-}

This work was funded by Comisión Sectorial de Investigación Científica (CSIC- UDELAR- Uruguay). The authors thank Mr. Carlos Belloso, company director of INOVUM S.R.L., who generously provided dyes and staining advice.

\section{References:-}

1. Abella, I. (2011): Uruguay, productor de lanas de calidad. In: 'XV Congreso Latinoamericano de Buiatría, XXXIX Jornadas Uruguayas de Buiatría’. pp. 185-188. (Paysandú, Uruguay).

2. Abella, I., Cardellino, R.C., Mueller, J., Cardellino, R.A., Benítez, D., Lira, R. (2010): South American Sheep and Wool Industries. In 'International Sheep and Wool Handbook'. (Ed. D. Cottle) pp. 85-94 (Nottingham, NG11 0AX, United Kingdom).

3. Andrews, R., Hawker, H., Littlejohn, R. (1988): Some aspects of the colour measurement of New Zealand wool, with emphasis on measurement by liquid scintillation spectrometry. New Zeal J Agr Res 31: $233-241$.

4. Aitken, F.J., Cottle, D.J., Reid, T.C., and Wilkinson, B.R. (1994): Mineral and amino acid composition of wool from New Zealand Merino sheep differing in susceptibility to yellowing. Aust J Agric Res 45 (2): $391-401$.

5. ASTM D2244-11 (2011): Standard Practice for Calculation of Color Tolerances and Color Differences from Instrumentally Measured Color Coordinates. ASTM International, West Conshocken, PA, American Society for Testing and Materials. Available at http://www.astm.org (accessed on 4 July 2018).

6. Bechtold, T., Mahmud-Ali, A., Mussak, R. (2007): Natural dyes for textile dyeing: A comparison of methods to assess the quality of Canadian golden rod plant material. Dyes Pigm 75: 287- 293.

7. Brady, R. (2005): Diffusion of dyes into Merino wool fibres. In 'Proceedings of the 11th International Wool Research Conference' (Leeds, England).

8. Capurro, G. (1996): Caracterización de la lana producida por la raza Corriedale en Uruguay. Lana Noticias 116: 22-26.

9. Cottle, D.J., Zhao, W., and Jones, J.C. (1992): Experiments to promote colour changes in wool. J Chem Technol Biotechnol 55 (4): 351-354.

10. Duffield, P., Lewis, D. (1985): The yellowing and bleaching of wool. Rev Prog Color Relat Top 15: 38-51.

11. Huntsman International LLC (2007): Textile Effects: POLAR®, ERIONYL® A, TECTILON@. Metallfreie Säure-Farbstoffe für Wolle und Polyamid metal-free acid dyes for wool and polyamide. Available at http://www.huntsman.com/textile (accessed on 4 July 2018).

12. IWTO-12 (2009): Measurement of the Mean and Distribution of Fibre Diameter Using the Sirolan-Laserscan Fibre Diameter Analyser. IWTO Red Book Specifications (International Wool Textile Organisation, Brussels Belgium).

13. IWTO 56 (2010): Method for the measurement of colour of raw wool. IWTO Red Book Specifications (International Wool Textile Organisation, Brussels Belgium).

14. Jaeckel, S., Ward, C. (1964): Fading of pastel colours on wool by light and sulphur dioxide. J. Soc. Dyers Color 80 (2): 72-82.

15. Lewis, D.M. (2009): The coloration of wool. In 'Advances in wool technology'. Ed. Woodhead Publishing Limited) pp.183-213 (Cambridge, England). 
16. Milligan, B. (1966): Studies in Wool yellowing Part XV: The yellowing of shrink-resistant wools under dyebath conditions. Text Res J 36 (11): 1012-1015.

17. Marler, J., Samuelsdorff, M. (1987): Observations on the influence of the colour of wool on its subsequent dyeing performance. II. Implications to the presale measurement of colour. International Wool Textile Organization, Technical Committee Paris. Report No.8.

18. MGAP (2018): http://www.mgap.gub.uy/noticia/unidad-organizativa/oficina-de-programacion-y-politicaagropecuaria/14-12-2017/expusieron-datos (accessed on 4 July 2018).

19. Peinado, G., Cardellino, R., Mendoza, J. (1999): El futuro de la demanda por lana Corriedale bajo la perspectiva del sector exportador. Lana Noticias 121: 27-31.

20. Peter, M., Rouette, H. (1989): 'Grundlagen der Textilveredlung. Hand buch der Technologie, Verfahren,Maschinen (13th edn).' (Deutscher Fachverlag, Frankfurt).

21. Reid, T. (1993): Variability in the susceptibility of wool to yellowing. Proc New Zeal Soc An 53: 315-518.

22. Reid, T. (1998): Wool Yellowing. Wool Tech Sheep Bree 46: 318-337.

23. Rottenbury, R. (1984) Colour of wool and processing. Wool Tech Sheep Bree 32: 190-196.

24. Skinner, J.N. (1958): The colour problem in Merino wool. Wool Tech Sheep Bree 5 (1): 139-142.

25. Stata Statistical Software StataCorp (2011): Release 7.0. College Station, TX, Stata Corporation. Stata Statistical Software: Release 7.0.

26. Teasdale, D.C. (1995): The Wool Handbook - The A to Z of Fibre to Top. (Croydon, New South Wales), pp. 1.

27. Whiteley, K., Samuelsdorff, M., Connell, J. (1987): Observations on the influence of the colour of wool on its subsequent dyeing performance. I. International Wool Textile Organization, Technical Committee. Paris. Report $\mathrm{N}^{\circ} 8$.

28. Willis, R. (1997): Objective color difference evaluation. Color Technology in the Textile Industry. Second Edition (Ed. AATCC Committee RA36) pp.97-99

29. Wood, E. (2003): Textile Properties of Wool and Other Fibres. Wool Tech Sheep Bree 51 (3): 272-290.

30. Wood, E. (2002): The basis of wool colour measurement. Wool Tech Sheep Bree 50: 121- 132. 